\title{
Boron-10 ABUNCL Models of Fuel Testing
}

Edward R. Siciliano

Azaree T. Lintereur

Richard T. Kouzes

James H. Ely

October 2013

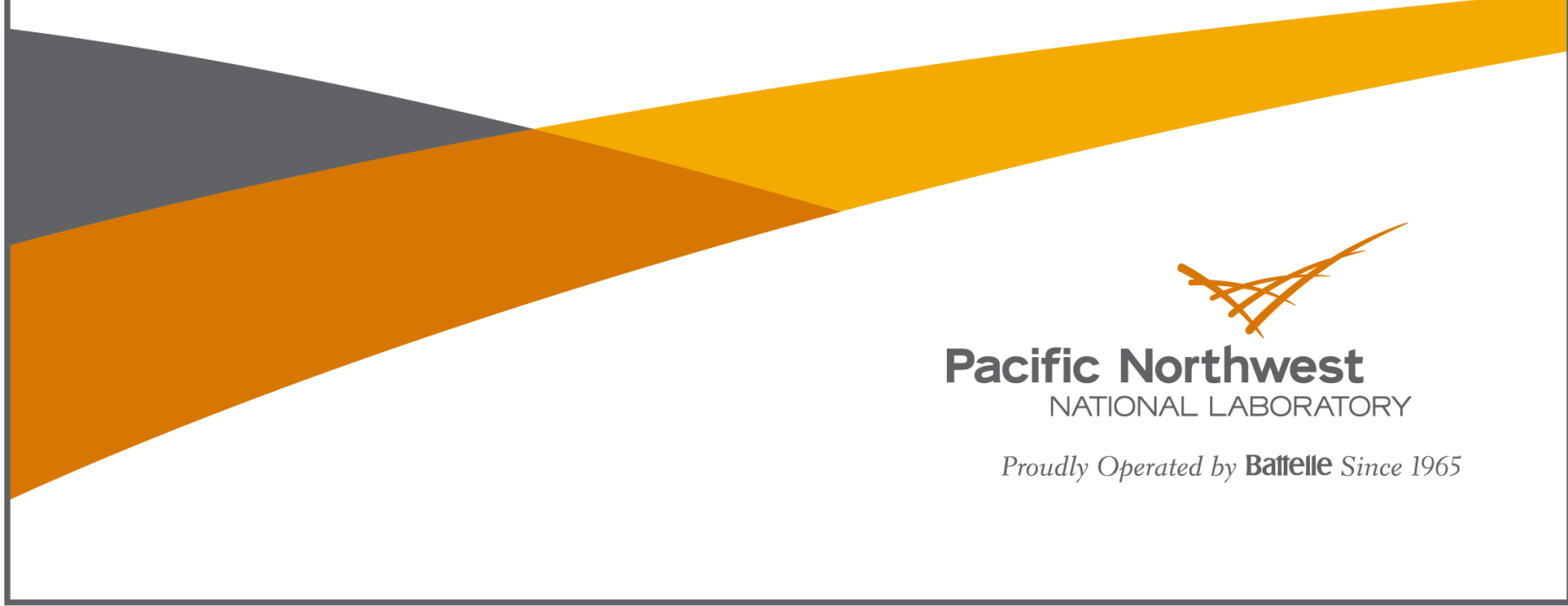




\title{
DISCLAIMER
}

This report was prepared as an account of work sponsored by an agency of the United States Government. Neither the United States Government nor any agency thereof, nor Battelle Memorial Institute, nor any of their employees, makes any warranty, express or implied, or assumes any legal liability or responsibility for the accuracy, completeness, or usefulness of any information, apparatus, product, or process disclosed, or represents that its use would not infringe privately owned rights. Reference herein to any specific commercial product, process, or service by trade name, trademark, manufacturer, or otherwise does not necessarily constitute or imply its endorsement, recommendation, or favoring by the United States Government or any agency thereof, or Battelle Memorial Institute. The views and opinions of authors expressed herein do not necessarily state or reflect those of the United States Government or any agency thereof.

\author{
PACIFIC NORTHWEST NATIONAL LABORATORY \\ operated by \\ BATTELLE \\ for the \\ UNITED STATES DEPARTMENT OF ENERGY \\ under Contract DE-AC05-76RL01830
}

Printed in the United States of America

\author{
Available to DOE and DOE contractors from the \\ Office of Scientific and Technical Information, \\ P.O. Box 62, Oak Ridge, TN 37831-0062; \\ ph: (865) 576-8401 \\ fax: (865) 576-5728 \\ email: reports@adonis.osti.gov
}

Available to the public from the National Technical Information Service, U.S. Department of Commerce, 5285 Port Royal Rd., Springfield, VA 22161

ph: (800) 553-6847

fax: (703) 605-6900

email: orders@ntis.fedworld.gov

online ordering: http://www.ntis.gov/ordering.htm 


\section{Boron-10 ABUNCL Models of Fuel Testing}

Edward R. Siciliano

Azaree T. Lintereur

Richard T. Kouzes

James H. Ely

October 2013

Pacific Northwest National Laboratory

Richland, Washington 99352 


\section{Executive Summary}

The Department of Energy Office of Nuclear Safeguards and Security (NA-241) is supporting the project Coincidence Counting With Boron-Based Alternative Neutron Detection Technology at Pacific Northwest National Laboratory (PNNL) for the development of a ${ }^{3} \mathrm{He}$ proportional counter alternative neutron coincidence counter. The goal of this project is to design, build and demonstrate a system based upon ${ }^{10} \mathrm{~B}$-lined proportional tubes in a configuration typical for ${ }^{3} \mathrm{He}-$ based coincidence counter applications.

This report provides results from MCNP simulations of the General Electric Reuter-Stokes Alternative Boron-Based Uranium Neutron Coincidence Collar (ABUNCL) active configuration model with fuel pins previously measured at Los Alamos National Laboratory. A comparison of the GE-ABUNCL simulations and simulations of ${ }^{3} \mathrm{He}$ based UNCL-II active counter (the system for which the GE-ABUNCL was targeted to replace) with the same fuel pin assemblies is also provided. 


\section{Acronyms and Abbreviations}

ABUNCL

AmLi

ASB

BWR

cps

D

DOE

DU

$\varepsilon$

FOM

FM4

GE

GERS

HDPE

IAEA

LANL

LEC

LEU

MCA

MOX

NCIA

NIM

NIST

PHL

PNNL

$\mathrm{Pu}$

$\mathrm{S}$

$\tau$

TB

TTL

$\mathrm{U}$

UNCL
Alternative Boron-Based Uranium Neutron Coincidence Collar

Americium-lithium neutron source

Active source block

Boiling water reactor

Counts per second

Doubles

U.S. Department of Energy

Depleted uranium

Detection efficiency

Figure of Merit

Flux Multiplier

General Electric

General Electric Reuter-Stokes

High Density Polyethylene

International Atomic Energy Agency

Los Alamos National Laboratory

Low-Energy Cutoff

Low-enriched uranium

Multi-Channel Analyzer

Mixed Oxide fuel

Neutron capture ion algorithm

Nuclear Instrumentation Module

National Institute of Science and Technology

Pulse-Height Light

Pacific Northwest National Laboratory

Plutonium

Singles

Die-away time

Tube block

Transistor-transistor logic

Uranium

Uranium Neutron Coincidence Collar 


\section{Contents}

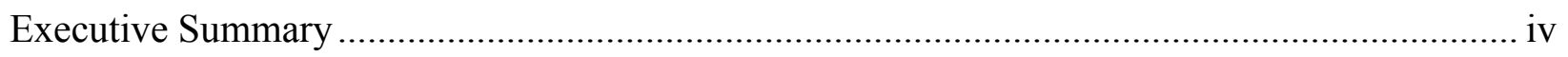

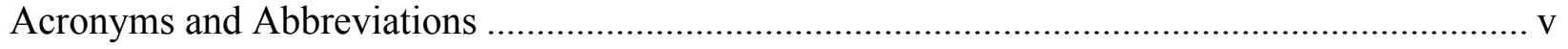

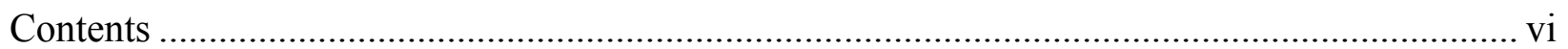

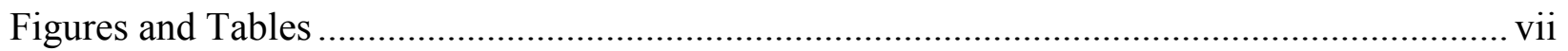

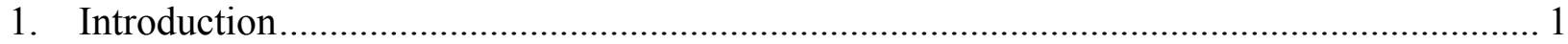

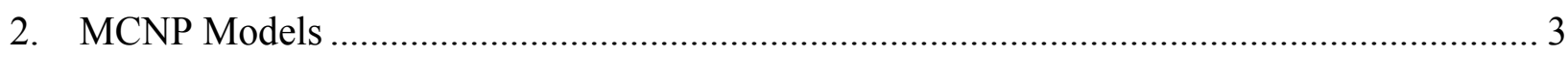

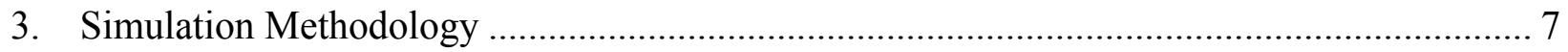

4. Simulation Results and Measurement Comparison ......................................................... 9

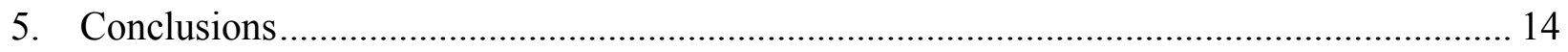

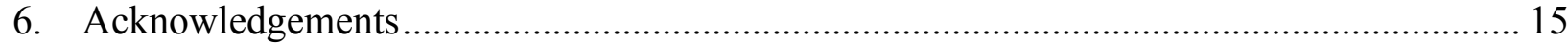

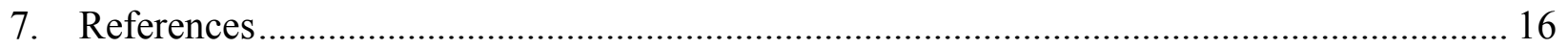

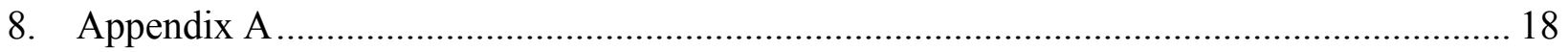

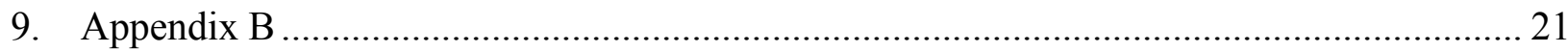




\section{Figures and Tables}

\section{Figures}

Figure 1.1. GE Reuter Stokes ABUNCL at LANL. ....................................................... 2

Figure 2.1. Detail of one of the simulated fuel array configurations........................................ 3

Figure 2.2. The eight simulated fuel array configurations, which correspond to those measured with the GE-ABUNCL. The blue circles correspond to DU fuel rod placement and the orange circles correspond to LEU fuel rod placement.................................................. 4

Figure 2.3. MCNPX model of GE-ABUNCL used for simulations with the fuel assemblies. ..... 4

Figure 2.4. GE-ABUNCL positioned around the fuel assembly at LANL (a), and the corresponding MCNPX model of the GE-ABUNCL and the fuel assembly (b)................ 5

Figure 2.5. MCNPX model of the UNCL-II and the fuel assembly.................................... 6

Figure 2.6. The Geiger-Zwan and Obninsk2 AmLi spectra used in the simulations................... 6

Figure 8.1. Active source block polyethylene volume alterations for the (a) GE-ABUNCL and (b) the UNCL-II. The images on the left show the original active block and the images on the right show the modified active blocks.

Figure 8.2. Polyethylene variations for the UNCL-II. The GE-ABUNCL footprint (a) is shown for comparison. An increase in the UNCL-II height to be the same as the GE-ABUNCL is shown in (b), the UNCL-II polyethylene volume change to be approximately equivalent to the GE-ABUNCL polyethylene volume is shown in (c), and the same polyethylene configuration, but with the tube size also increased to be the same as the GE-ABUNCL tube height, is shown in (d). 19

Figure 9.1. Variations in fuel height simulated in both the GE-ABUNCL (shown) and the UNCL-II (not shown). The seventh simulated height (h) is not shown 22

\section{Tables}

Table 1.1. Characteristics of UNCL and GE-ABUNCL configurations [Kouzes 2012].............. 1

Table 4.1. Measured and simulated results with a ${ }^{252} \mathrm{Cf}$ source located in the center of the sample chamber......

Table 4.2. Measured and simulated results with the UNCL-II and GE-ABUNCL using AmLi and ${ }^{252} \mathrm{Cf}$ sources. The sources were located in the source location in the active block of the counters. The configurations that were not measured are indicated by NM..

Table 4.3. Measured and simulated singles with the GE-ABUNCL and the eight fuel array configurations that were shown in Figure 2.2 ....................................................... 11

Table 4.4. Measured and simulated doubles with the GE-ABUNCL and the eight fuel array configurations shown in Figure 2.2. 
Table 4.5. Simulated singles and doubles in DU, LEU and modified LEU fuel compositions.... 12

Table 4.6. Measurements and simulations of the singles rates with the fuel assembly (Array Number 8$)$ in the center of the chamber, shifted $3.75 \mathrm{~cm}$ towards the AmLi source $(+3.75$ $\mathrm{cm})$ and shifted $3.75 \mathrm{~cm}$ away from the AmLi source $(-3.75 \mathrm{~cm})$.

Table 4.7. Measurements and simulations of the doubles rates with the fuel assembly (Array Number 8$)$ in the center of the chamber, shifted $3.75 \mathrm{~cm}$ towards the AmLi source $(+3.75$ $\mathrm{cm})$ and shifted $3.75 \mathrm{~cm}$ away from the AmLi source $(-3.75 \mathrm{~cm})$.

Table 4.8. Simulated doubles with the UNCL-II and the eight different fuel array assemblies compared to the simulated doubles with the GE-ABUNCL .......................................... 13

Table 8.1. The effect of the active source block dimensions on the neutron collisions and captures for both counters, and the effect of changes in the total amount of polyethylene on the neutron collisions and captures in the UCNL-II. ................................................ 20

Table 9.1. Simulated singles with the UNCL-II for the eight different fuel array assemblies, compared to the simulated singles with the GE-ABUNCL (Table 4.3). The percent difference was calculated using the simulated UNCL-II rates as the actual rates.

Table 9.2. Fuel height study with Array number 1 (all DU) and Array number 8 (all LEU) with the GE-ABUNCL. The original fuel assembly height was $128.0 \mathrm{~cm}$............................. 22

Table 9.3. Fuel height study with Array number 1 (all DU) and Array number 8 (all LEU) with

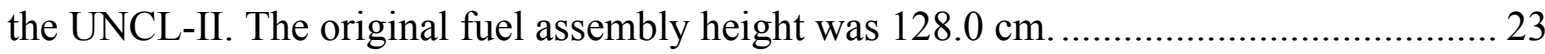




\section{Introduction}

One of the important safeguards applications of ${ }^{3} \mathrm{He}$ has been for coincidence counting instruments utilized by the International Atomic Energy Agency (IAEA). The Department of Energy Office of Nuclear Safeguards and Security (NA-241) has been supporting the project Coincidence Counting With Boron-Based Alternative Neutron Detection Technology at Pacific Northwest National Laboratory (PNNL) for the development of an alternative to the ${ }^{3} \mathrm{He}$ proportional counter based Uranium Neutron Coincidence Collar (UNCL). The goal of this project is to design, build and demonstrate a system based upon ${ }^{10} \mathrm{~B}$-lined proportional tubes in a configuration typical for ${ }^{3} \mathrm{He}$-based coincidence counter applications.

The search for technological alternatives to ${ }^{3} \mathrm{He}$ is a major research area in nuclear security and safeguards due to the shortage of this gas in recent years [Kouzes 2010; Menlove 2011]. General Electric (GE) Reuter-Stokes (Twinsburg, $\mathrm{OH}$ ) developed a passive coincidence collar prototype based on arrays of ${ }^{10} \mathrm{~B}$-lined tubes filled with Ar gas. That prototype was loaned to PNNL for testing to assess its performance compared to safeguards requirements for an Alternative Boronbased Uranium Neutron Coincidence Collar (ABUNCL) [McKinny 2012; Kouzes 2012]. The GE-ABUNCL was reconfigured for use in an active mode, and initial testing of the active configuration was performed at PNNL [Kouzes 2013]. Subsequently, the GE-ABUNCL was taken to Los Alamos National Laboratory (LANL) for testing with fresh low-enriched uranium (LEU) and depleted uranium (DU) fuel pins [Kouzes 3013b]. Listed in Table 1.1 is comparative data characterizing the two ${ }^{3} \mathrm{He}$-based active BWR UNCL configurations, and the GEABUNCL. Since the ABUNCL has lower performance than the UNCL, testing was to determine if this performance is adequate for safeguards use.

Table 1.1. Characteristics of UNCL and GE-ABUNCL configurations [Kouzes 2012].

\begin{tabular}{|c|c|c|c|c|c|c|c|c|}
\hline \multirow{3}{*}{ Detector } & \multirow{3}{*}{$\begin{array}{c}\text { Total \# Tubes, } \\
\text { Configuration, \& } \\
\text { Fuel Cavity } \\
\text { H x L x W (cm) }\end{array}$} & \multirow{3}{*}{$\begin{array}{l}\text { Total } \\
\text { No. } \\
\text { Moles }\end{array}$} & \multicolumn{6}{|c|}{ Efficiency $(\varepsilon)$, Die-Away Time $(\tau) \&$ FOM $=\varepsilon^{2} / \tau$} \\
\hline & & & \multicolumn{3}{|c|}{ Measurement Results } & \multicolumn{3}{|c|}{ Model Results } \\
\hline & & & $\varepsilon$ & $\begin{array}{c}\tau \\
(\mu \mathbf{s})\end{array}$ & $\begin{array}{c}\text { FOM } \\
(\%)^{2} / \mu \mathrm{s}\end{array}$ & $\varepsilon$ & $\begin{array}{c}\tau \\
(\mu \mathbf{s})\end{array}$ & $\begin{array}{c}\text { FOM } \\
(\%)^{2} / \mu \mathrm{s}\end{array}$ \\
\hline $\begin{array}{l}\text { UNCL-I } \\
\text { Active } \\
\text { BWR }\end{array}$ & $\begin{array}{l}18{ }^{3} \mathrm{He} \text { tubes } \\
3 \text { Rectangular banks, } \\
41.4 \times 16.5 \times 23.4\end{array}$ & 0.44 & $13.5 \% *$ & & & $12.5 \%$ & 50 & 3.1 \\
\hline $\begin{array}{l}\text { UNCL-II } \\
\text { Active } \\
\text { BWR }\end{array}$ & $\begin{array}{l}16{ }^{3} \mathrm{He} \text { tubes } \\
3 \text { Rectangular banks } \\
41.3 \times 16.5 \times 16.5\end{array}$ & 0.39 & $\begin{array}{c}15.3 \% * * \\
15.4 \% * \\
13.5 \% \\
( \pm 10 \%)^{* * *}\end{array}$ & $58 * *$ & 4.0 & $14.9 \%$ & 53 & 4.2 \\
\hline $\begin{array}{l}\text { GE RS } \\
\text { ABUNCL } \\
\text { Active } \\
\text { BWR**** }\end{array}$ & $\begin{array}{l}56{ }^{10} \mathrm{~B} \text {-lined tubes } \\
3 \text { Rectangular banks } \\
78.1 \times 16.5 \times 23.4\end{array}$ & NA & $9.4 \%$ & 83 & 1.1 & $11.5 \%$ & 77 & 1.7 \\
\hline
\end{tabular}

* $\quad$ From [Menlove et al. 1990] using ${ }^{252} \mathrm{Cf}$ centered in sample chamber

** From [Croft et al. 2011] using ${ }^{252} \mathrm{Cf}$ centered in sample chamber

*** From [Canberra 2011] for JCC-72 using active measurement

**** From [Kouzes 2013] using a $150 \mathrm{keV}$ low energy threshold 
Figure 1.1 shows the GE-ABUNCL in the lab at LANL being prepared for measurements on various configurations of fuel pins. The GE-ABUNCL system was tested with fuel pin assemblies at LANL on June 11-12, 2013 [Kouzes 2013b].

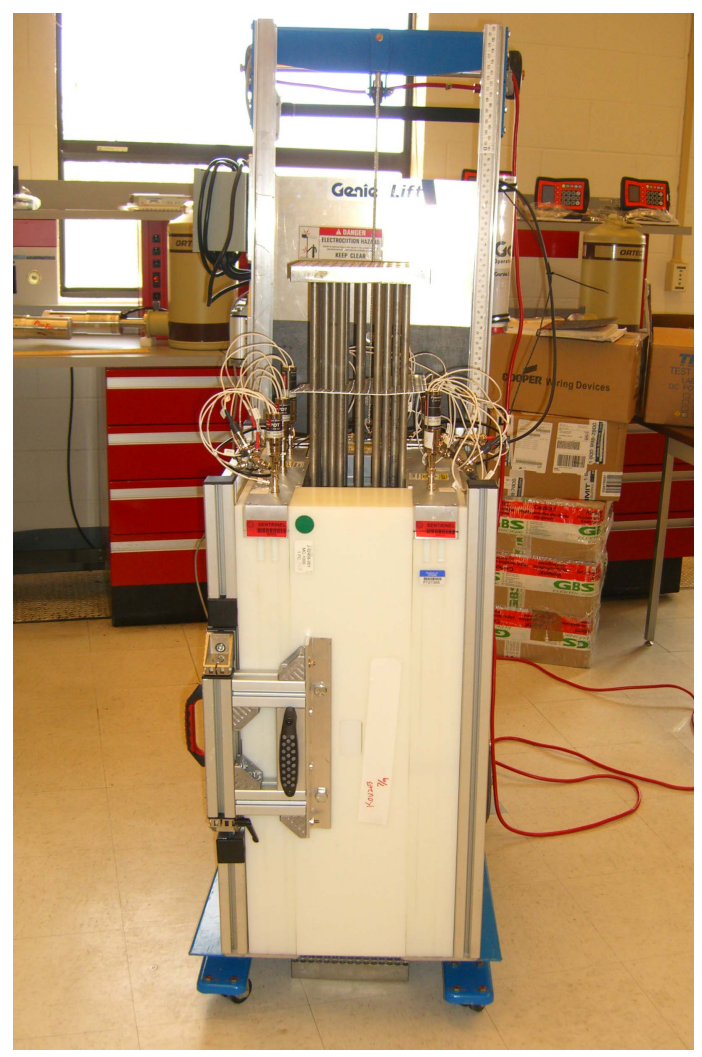

Figure 1.1. GE Reuter Stokes ABUNCL at LANL.

Reported here are simulation results generated with MCNP using the EDEP CAP option available in MCNP6 v.1.0. The simulations were performed for the same fuel pin configurations that were measured. The measured and simulated results are compared to validate the application of the simulation methodology to detectors where the neutron capture and signal generating material are not the same (i.e., ${ }^{10} \mathrm{~B}$-lined proportional counters filled with argon). Because the GE-ABUNCL system was targeted to replace the ${ }^{3} \mathrm{He}$-based UNCL-II counter, simulations were also performed with a previously developed, UNCL-II model for comparison. 


\section{MCNP Models}

The measurements made at LANL [Kouzes 2013b] used 72 fuel pins (DU and/or LEU) in a $9 \times 9$ array with an additional 8 guide pins around the outside of the fuel pins. Eight different fuel lattice array configurations were measured, including all DU and all LEU fuel, and mixtures of each. Both the DU $\left(0.219 \%{ }^{235} \mathrm{U}\right)$ and LEU $\left(3.19 \%{ }^{235} \mathrm{U}\right)$ fuel were surrounded by zircaloy cladding, as can be seen in Figure 2.1. The guide pins seen in Figure 2.1 were constructed of steel. Simulations with MCNP were performed with fuel assembly models that corresponded to those measured [Kouzes 2013b]. The fuel lattice array configurations simulated are shown in Figure 2.2.

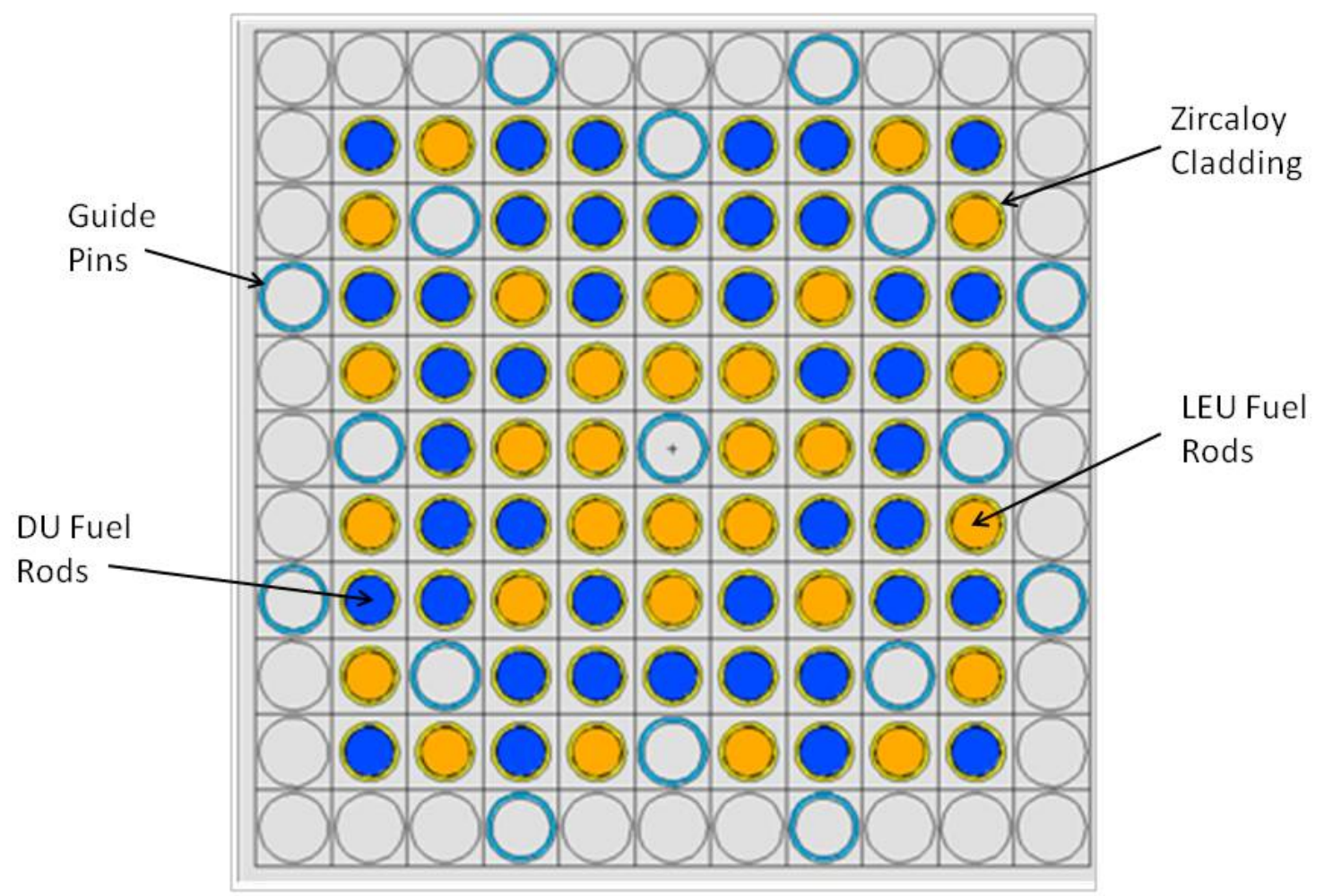

Figure 2.1. Detail of one of the simulated fuel array configurations. 


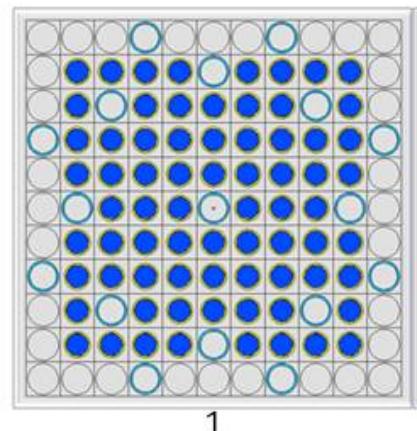

1

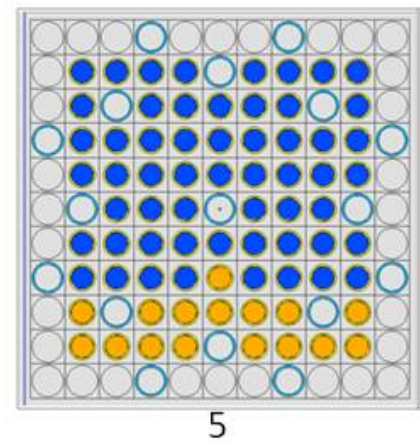

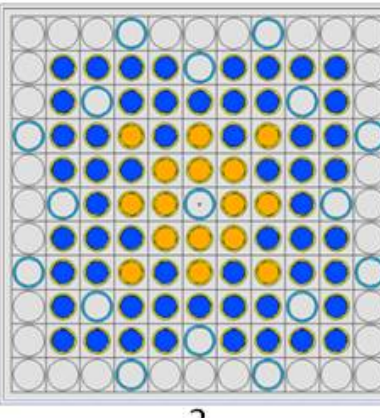

2
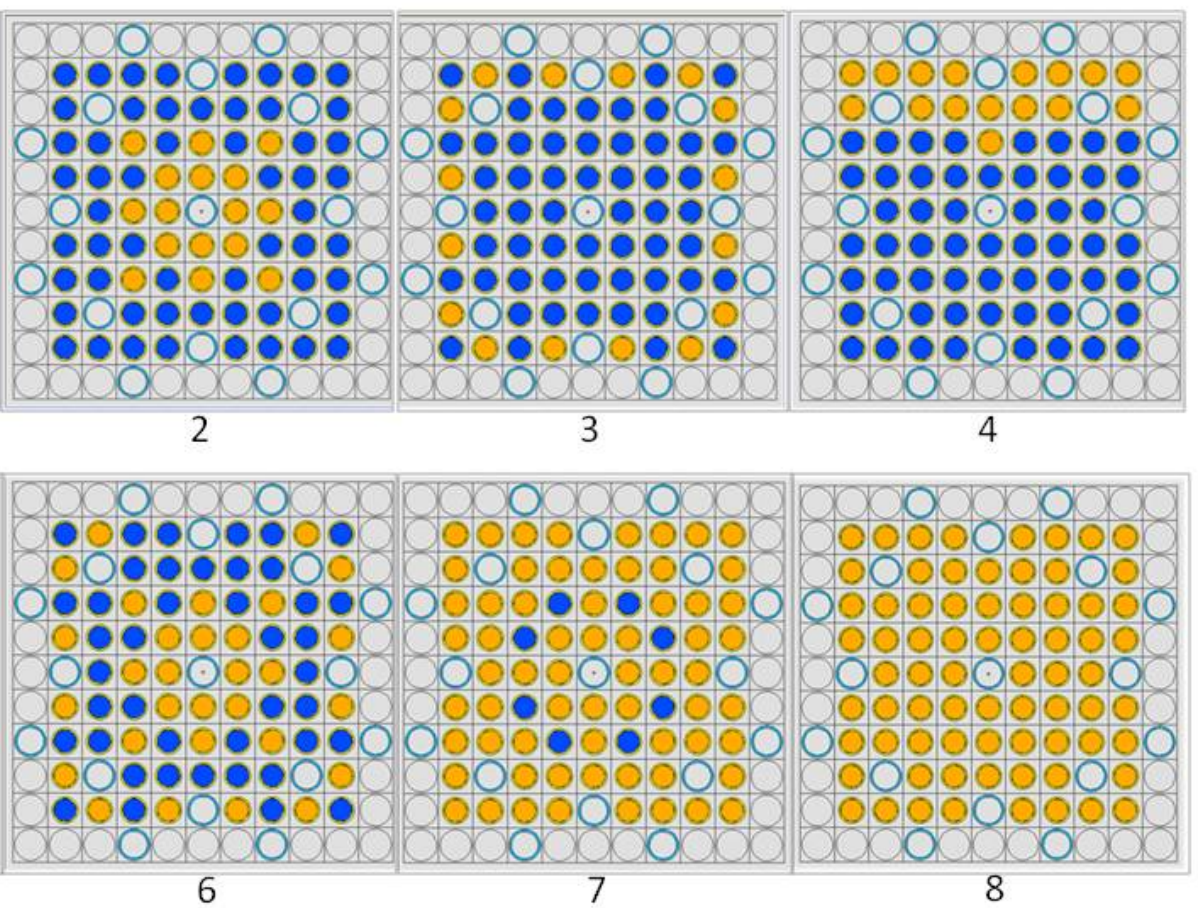

Figure 2.2. The eight simulated fuel array configurations, which correspond to those measured with the GE-ABUNCL. The blue circles correspond to DU fuel rod placement and the orange circles correspond to LEU fuel rod placement.

The previously developed GE-ABUNCL model [Kouzes 2013], shown in Figure 2.3, was used for the simulations with the fuel assemblies. The detector was positioned around the fuel assembly in the models to match the measurement configuration, as shown in Figure 2.4. The base of the detector was located $17 \mathrm{~cm}$ above the floor, and the fuel assembly was centered in the sample chamber.
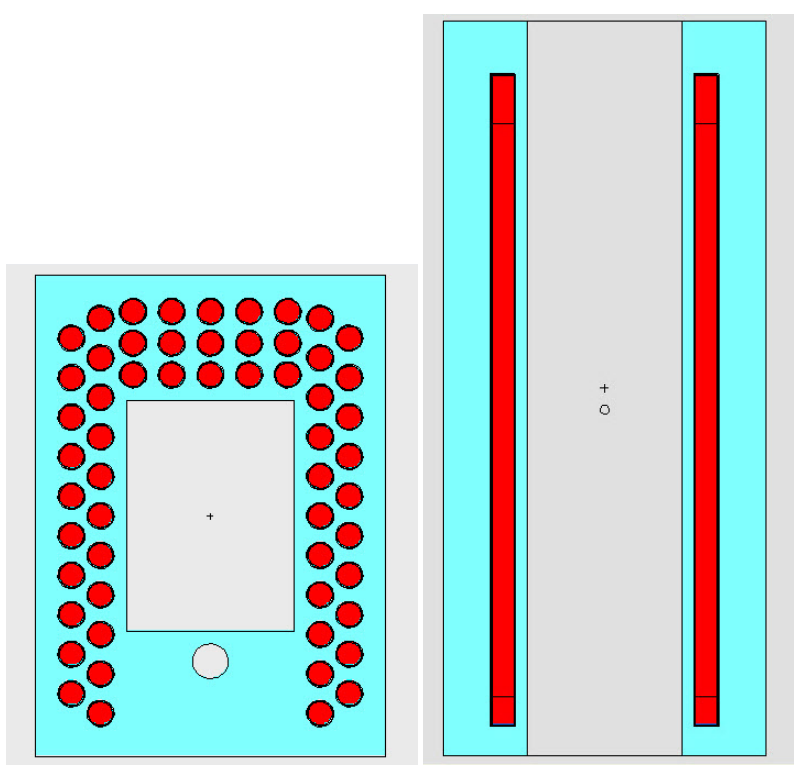

Figure 2.3. MCNPX model of GE-ABUNCL used for simulations with the fuel assemblies. 


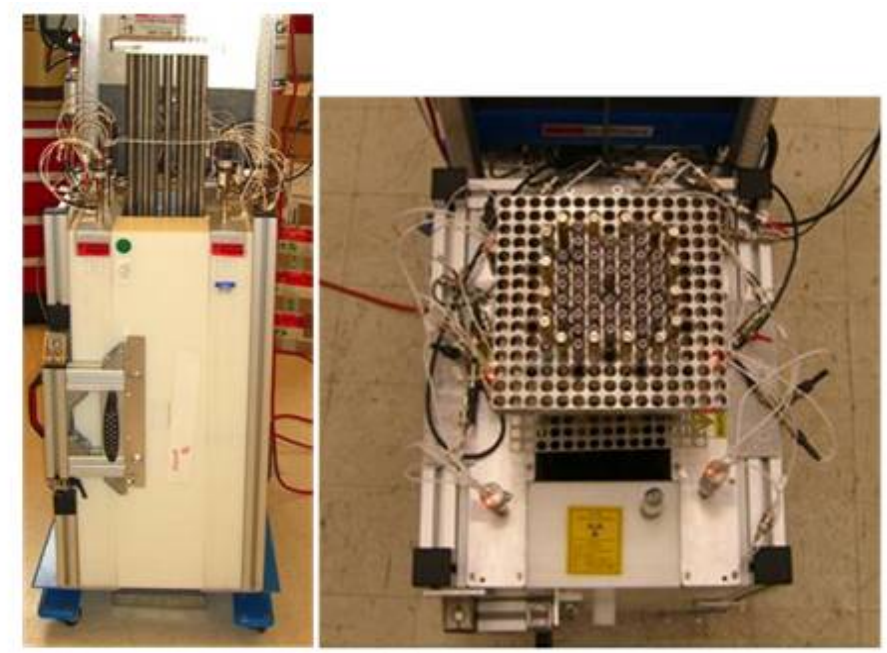

(a)

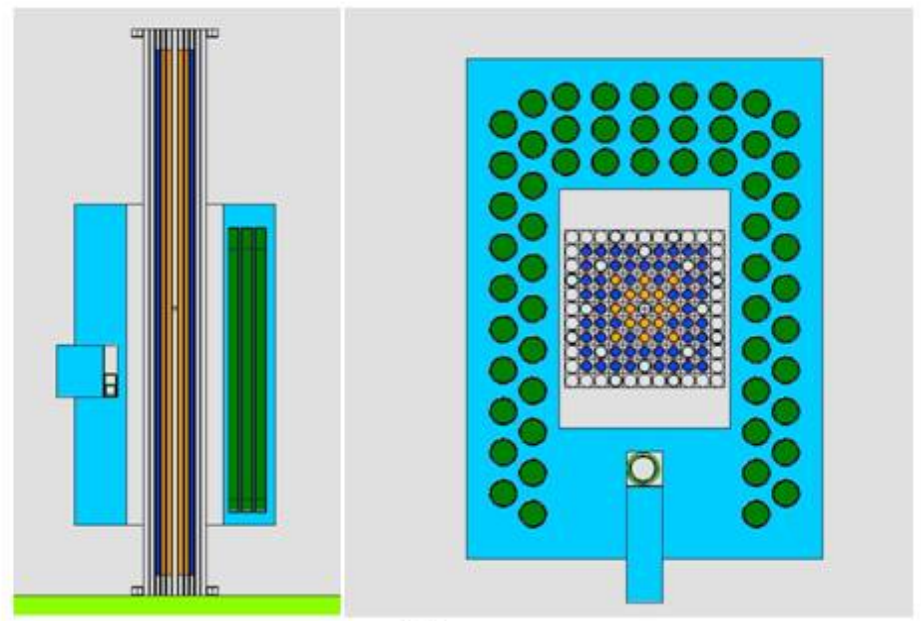

(b)

Figure 2.4. GE-ABUNCL positioned around the fuel assembly at LANL (a), and the corresponding MCNPX model of the GE-ABUNCL and the fuel assembly (b).

Simulations were also performed with the ${ }^{3} \mathrm{He}$ based UNCL-II BWR-Active model [Siciliano 2012] using the eight different fuel assembly configurations shown in Figure 2.2. The UNCL-II is shown with the fuel assembly in Figure 2.5; notice the difference in the chamber size of the UCNL-II compared to the GE-ABUNCL. The UNCL-II was positioned such that the center of the active length of the ${ }^{3} \mathrm{He}$ tubes was at the same location as the center of the active length of the ${ }^{10} \mathrm{~B}$-lined tubes in the GE-ABUNCL, which corresponded to the base being located a height of $21.5 \mathrm{~cm}$ above the floor. 


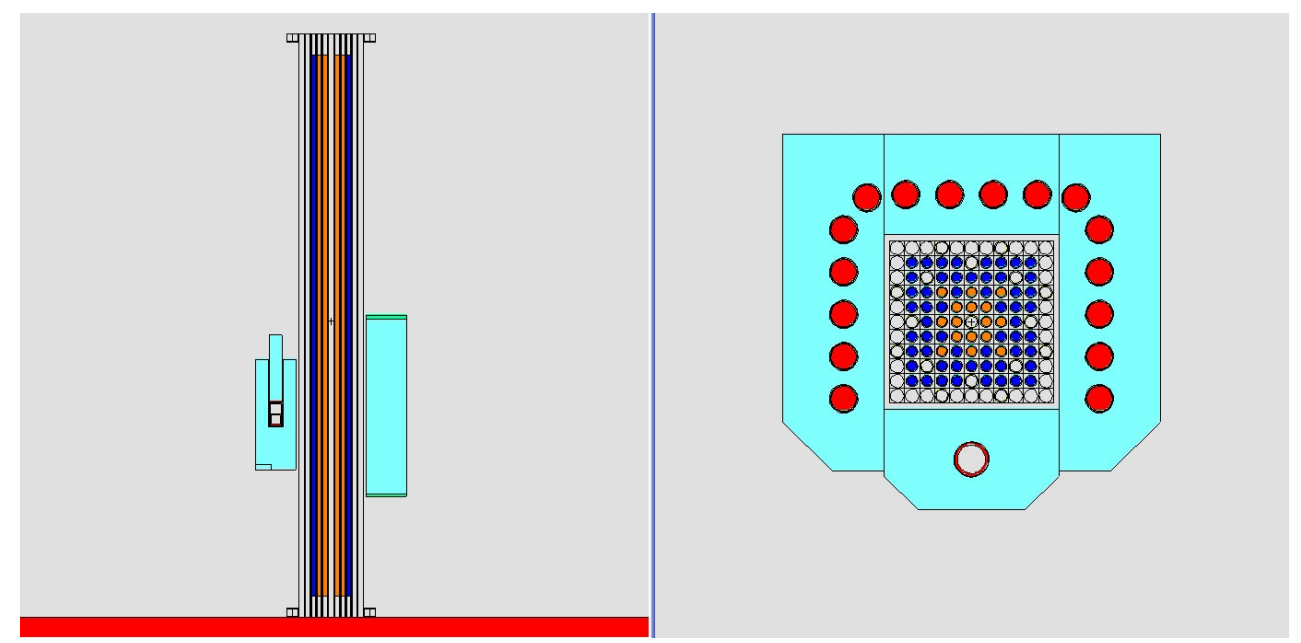

Figure 2.5. MCNPX model of the UNCL-II and the fuel assembly.

There are two different commonly used AmLi source spectra, the Oblinsk2 spectrum and the Geiger-Van de Zwan spectrum [Croft 20111]. The Oblinsk2 spectrum is harder than the GeigerVan de Zwan spectrum, both of which are shown in Figure 2.6. Given that the spectra of the AmLi sources used for the measurements were unknown, both source options were used in the simulations to examine difference in the simulated doubles rates that may result from the AmLi source spectra.

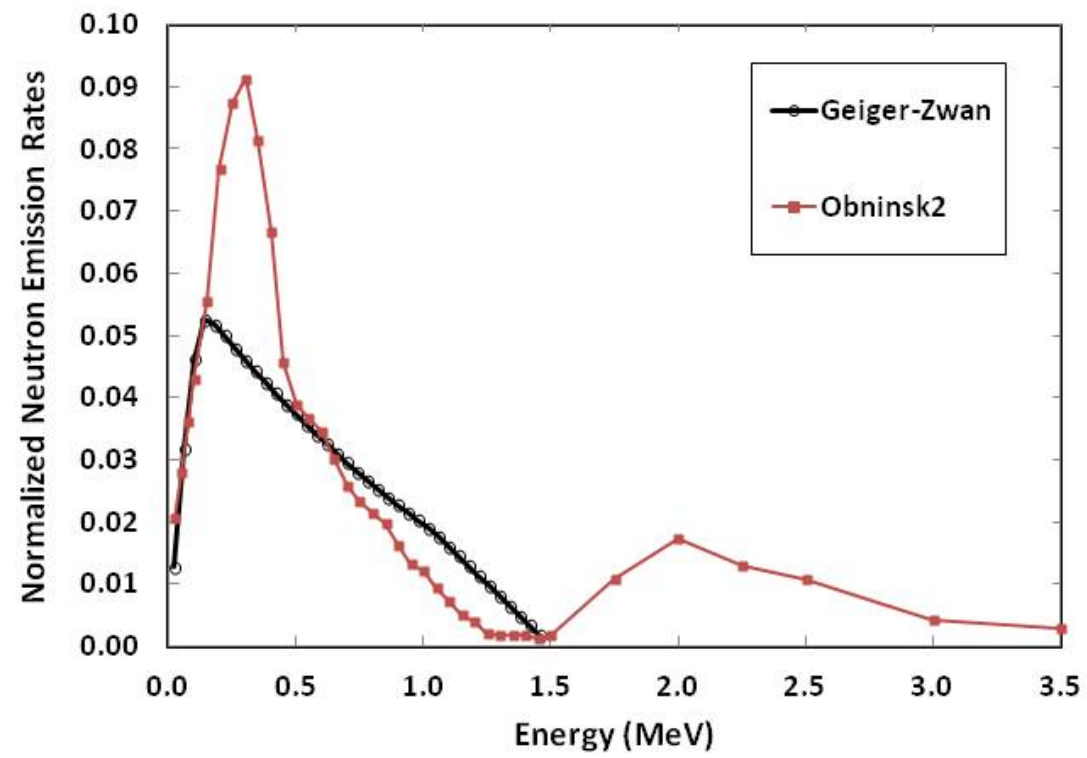

Figure 2.6. The Geiger-Zwan and Obninsk2 AmLi spectra used in the simulations. 


\section{Simulation Methodology}

The latest versions of the MCNP codes (i.e., MCNP5 v1.60; MCNPX v2.70; and their successor, MCNP6 v1.0 [Goorley 2013]) offer a number of different tally types and options for simulating neutron detectors. The choice among the different methods depends on the neutron reaction material, its relation to the signal-generating material, and the type of measurements the model is trying to simulate.

For detectors that record only the total neutron count rates and use ${ }^{3} \mathrm{He}\left(\right.$ or $\left.\mathrm{BF}_{3}\right)$ gas-filled proportional counters, calculating the total number of capture reactions in the active volume of gas has historically given very good agreement with measured values [Kouzes 2010]. The MCNP method for obtaining this result is the F4-type (track length) tally with a flux multiplier (FM4) for the specific capture reaction cross section. The output is the total number of neutron reactions per source neutron that takes place in the volume of reaction material. As long as the volume cell of material in which the neutron reaction occurs is the same cell which generates the signal, then the calculated total number of captures per emitted neutron can be equated to the counting efficiency of the modeled detector.

Note that the F4/FM4 total capture-counting method does not provide any further information about the signal-generating process, such as the pulse-height distribution of the signal caused by the energy deposition from the reaction products slowing down in the gas. Nor does it apply to total count rates from detectors that use boron-lined proportional counters, where the total energy deposited by the reaction products is reduced as they escape from the lining cell into the gasfilled signal-generating cell. Both these shortcomings to the F4/FM4 method can be addressed by using the correlated pulse-height "light" treatment to the F8 tally, i.e., FT8 PHL. This option uses the F8 tally arrays to register counts based upon energy or light deposition from one or two F6-type tallies, in the same or different cells. Assigning these F6 tallies to the reaction products, and using the neutron capture ion algorithm (NCIA) option to ensure the correlation of these depositions, enables this method to give pulse-height distributions in the signal-generating cell whether or not it is the same as the capture cell. Thus, this option is applicable to either ${ }^{3} \mathrm{He}$ or boron lined counters.

Detection systems used for safeguard measurements of $\mathrm{U}$ and $\mathrm{Pu}$, record, via a shift-register, singles, doubles, and triples count rates for a sample. To calculate these quantities, the coincidence capture tally treatment was added to the pulse-height tally, i.e., FT8 CAP, with predelay and gate-width time bin values set by the user. This tally treatment converts the F8 pulseheight tally to a neutron capture tally, sets the fission multiplicity option, uses analog transport, and computes the multiplicity moments per history-initiating neutron. It has been available in MCNPX since version 2.50 [Hendricks 2005] and has been applied successfully to simulate the shift-register count rates from ${ }^{3} \mathrm{He}$-based coincidence counters [e.g., see Swinhoe 2005]. Because its implementation in MCNPX assumed the capture cells were the same as the signalgenerating cells, the MCNPX application of the FT8 CAP tally cannot be used to simulate the ${ }^{10} \mathrm{~B}$-lined detectors. This restriction was eliminated in the MCNP6 implementation of the FT8 CAP tally, where in addition to allowing for the capture and signal-generating cells to be 
different; it now also has an optional EDEP parameter that provides a lower-energy cutoff to the total deposited energy used when calculating the multiplicity moments [Swinhoe 2011].

The MCNP tally parameters used for the results listed in this report are as follows. For the GEABUNCL calculations, the FT8 CAP EDEP treatment was evaluated with and without timing gate bins to obtain the (total-capture) singles values and the (coincidence-capture) doubles values. To correspond to the values used in the GE-ABUNCL measurements, the EDEP parameter was fixed to $150 \mathrm{keV}$. Similarly, for the doubles tallies, the timing gate values were set to $4.0 \mu \mathrm{s}$ for the pre-delay, and $100 \mu \mathrm{s}$ for the gate-width. For the UNCL-II calculations, the FT8 CAP treatment was evaluated, again with and without timing gate bins. The pre-delay and gate width time bins used for doubles were adopted from the UNCL-II-BWR results reported by Croft et al. [Croft 2011] to be $4.5 \mu$ s and $64 \mu$ s, respectively.

All the results presented in this report were obtained using a HDPE density of $0.96 \mathrm{~g} / \mathrm{cm}^{3}$, noting that for the UNCL-II-BWR active collar calculations, guided by the previous MCNPX modeling of the active UNCL-II-BWR collar [Swinhoe 2005], the value used was $0.95 \mathrm{~g} / \mathrm{cm}^{3}$. Also reported by Swinhoe et al. is a variation of $\sim 1.6 \%$ in the doubles when the density was varied from $0.93 \mathrm{~g} / \mathrm{cm}^{3}$ to $0.95 \mathrm{~g} / \mathrm{cm}^{3}$. The default cross-section libraries were used (mostly the ENDFB-VII), and all calculations were performed using $1 \times 10^{7}$ neutron histories. The result gave statistical uncertainties of less than $1 \%$ for the singles and the double rates. 


\section{Simulation Results and Measurement Comparison}

The first set of simulations performed with the FT8 EDEP CAP option was with a ${ }^{252} \mathrm{Cf}$ source in the center of the sample chamber for both the GE-ABUNCL and the UNCL-II, and the results compared to those generated with the F8 PHL tally option and previously reported [Kouzes 2013]. For all of the simulations $1 \times 10^{7}$ neutron histories were evaluated, giving statistical errors of less than $1 \%$ for all of the tally results, including the doubles. The results from the ${ }^{252} \mathrm{Cf}$ simulations are shown in Table 4.1. The simulated results are the same as those previously generated with the F8 PHL tally option (Table 1.1). Note that the ratio of the simulated to the measured efficiency (for the singles) is approximately 1.2.

Table 4.1. Measured and simulated results with a ${ }^{252} \mathrm{Cf}$ source located in the center of the sample chamber.

\begin{tabular}{|c|c|c|}
\hline Configuration & $\begin{array}{l}\text { Measured cps/emitted } \\
\text { source neutron }\end{array}$ & $\begin{array}{c}\text { Simulated cps/emitted } \\
\text { source neutron }\end{array}$ \\
\hline${ }^{252} \mathrm{Cf}, \mathrm{UNCL}-\mathrm{II}$ & $\begin{array}{c}15.3 \% * * \\
15.4 \% * \\
13.5 \% \\
( \pm 10 \%)^{* * *}\end{array}$ & $15.0 \%$ \\
\hline $\begin{array}{l}{ }^{252} \mathrm{Cf}, \mathrm{GE}- \\
\text { ABUNCL }\end{array}$ & $9.4 \% * * * *$ & $11.6 \%$ \\
\hline $\begin{array}{ll}* & \text { From [ } \\
* * & \text { From [ } \\
* * * & \text { From [ } \\
* * * * & \text { From [ }\end{array}$ & $\begin{array}{l}\text { enlove et al. 1990] using } \\
\text { oft et al. 2011] using }{ }^{252} \mathrm{C} \\
\text { nberra 2011] for JCC-72 } \\
\text { uzes 2013] using a } 150 \mathrm{k}\end{array}$ & $\begin{array}{l}\text { f centered in sample char } \\
\text { ntered in sample chambe } \\
\text { ag active measurement } \\
\text { low energy threshold }\end{array}$ \\
\hline
\end{tabular}

The next set of simulations, again performed with both detectors, was with an AmLi source, and then $\mathrm{a}^{252} \mathrm{Cf}$ source, in the source holder of the active wall of each of the counters. The results of the simulations are shown in Table 4.2. The efficiency of the UNCL-II is higher than the GEABUNCL for a source located in the center of the sample cavity, as was shown in Table 4.1. However, as can be seen in Table 4.2, for a source located in the active block of the counter the efficiency of the GE-ABUNCL is higher. The difference in the efficiency with source location can be traced to the size difference of the counters, and the number of interactions that take place. These effects are discussed in Appendices A and B. 
Table 4.2. Measured and simulated results with the UNCL-II and GE-ABUNCL using AmLi and ${ }^{252} \mathrm{Cf}$ sources. The sources were located in the source location in the active block of the counters. The configurations that were not measured are indicated by NM.

\begin{tabular}{||c|c|c|c|c||}
\hline Configuration & $\begin{array}{c}\text { Measured } \\
\text { cps/emitted source } \\
\text { neutron }\end{array}$ & $\begin{array}{c}\text { Measured } \\
\text { doubles/emitted } \\
\text { source neutron }\end{array}$ & $\begin{array}{c}\text { Simulated } \\
\text { cps/emitted } \\
\text { source neutron }\end{array}$ & $\begin{array}{c}\text { Simulated } \\
\text { doubles/emitted } \\
\text { source neutron }\end{array}$ \\
\hline AmLi, UCNL-II & NM & N/A & $5.6 \%$ & 0 \\
\hline $\begin{array}{c}\text { AmLi, GE- } \\
\text { ABUNCL }\end{array}$ & $5.5 \%$ & N/A & $6.7 \%$ & 0 \\
\hline${ }^{252}$ Cf, UNCL-II & NM & NM & $6.45 \%$ & $0.27 \%$ \\
\hline${ }^{252}$ Cf, GE- & $5.5 \%$ & $0.26 \%$ & $6.62 \%$ & $0.34 \%$ \\
\hline ABUNCL & 5 & &
\end{tabular}

After the single source simulations were performed, both the GE-ABUNCL and the UNCL-II models were run with the various fuel assembly configurations (shown in Section 2).

The simulated singles and doubles with the GE-ABUNCL for the different fuel assembly configurations were compared to the measured values [Kouzes 2013b], as listed in Table 4.3 and Table 4.4. The measured results were used as the actual for the percent difference calculation. The precision of the measured results was found to be $\sim 1 \%$ [Kouzes 2013b]. The singles are dominated by the source, and the model consistently overestimates the rate compared to the measurements by $\sim 17 \%$.

As discussed in the previous report [Kouzes 2013b], the measured doubles rate increased with the amount of LEU in the system. The simulated results with both the Geiger-Van de Zwan and the Oblinsk 2 source are presented, and also increase with the amount of LEU in the system. As with the ${ }^{252} \mathrm{Cf}$ results, the ratio of the simulated to measured efficiency (for the singles rates) is approximately 1.2 for both the Geiger Zwan and the Oblinsk2 AmLi spectra. The doubles results show more variation (ranging from $8 \%$ to $26 \%$ ) than the singles, but there is little evident dependency of the simulated doubles rate upon the AmLi source spectra. The consistent overestimate of the model cannot be attributed to any specific cause. 
Table 4.3. Measured and simulated singles with the GE-ABUNCL and the eight fuel array configurations that were shown in Figure 2.2.

\begin{tabular}{|c|c|c|c|c|c|}
\hline $\begin{array}{c}\text { Array } \\
\text { Number }\end{array}$ & $\begin{array}{c}\text { Measured } \\
\text { cps/emitted } \\
\text { AmLi neutron } \\
(\%)\end{array}$ & $\begin{array}{c}\text { Simulated } \\
\text { cps/emitted AmLi } \\
\text { neutron (\%) (G-Z } \\
\text { AmLi Spectrum) }\end{array}$ & $\begin{array}{c}\text { Simulated cps/emitted } \\
\text { AmLi neutron (\%) } \\
\text { (Oblinsk2 AmLi } \\
\text { Spectrum) }\end{array}$ & $\begin{array}{c}\% \\
\text { Difference } \\
\text { (Geiger } \\
\text { Zwan) }\end{array}$ & $\begin{array}{c}\text { \% } \\
\text { Difference } \\
\text { (Oblinsk2) }\end{array}$ \\
\hline $\mathbf{1}$ & 6.1 & 7.2 & 7.0 & $-17 \%$ & $-14 \%$ \\
\hline $\mathbf{2}$ & 6.5 & 7.7 & 7.5 & $-18 \%$ & $-15 \%$ \\
\hline $\mathbf{3}$ & 6.6 & 7.8 & 7.6 & $-18 \%$ & $-16 \%$ \\
\hline $\mathbf{4}$ & 6.4 & 7.5 & 7.4 & $-18 \%$ & $-15 \%$ \\
\hline $\mathbf{5}$ & 6.6 & 7.8 & 7.7 & $-19 \%$ & $-16 \%$ \\
\hline $\mathbf{6}$ & 6.9 & 8.1 & 7.9 & $-17 \%$ & $-15 \%$ \\
\hline $\mathbf{7}$ & 7.3 & 8.6 & 8.4 & $-18 \%$ & $-16 \%$ \\
\hline $\mathbf{8}$ & 7.3 & 8.6 & 8.5 & $-18 \%$ & $-16 \%$ \\
\hline
\end{tabular}

Table 4.4. Measured and simulated doubles with the GE-ABUNCL and the eight fuel array configurations shown in Figure 2.2.

\begin{tabular}{|c|c|c|c|c|c||}
\hline $\begin{array}{c}\text { Array } \\
\text { Number }\end{array}$ & $\begin{array}{c}\text { Measured } \\
\text { doubles/emitted } \\
\text { AmLi neutron } \\
\mathbf{( \% )}\end{array}$ & $\begin{array}{c}\text { Simulated } \\
\text { doubles/emitted } \\
\text { AmLi neutron (\%) } \\
\text { (G-Z AmLi } \\
\text { Spectrum) }\end{array}$ & $\begin{array}{c}\text { Simulated } \\
\text { doubles/emitted } \\
\text { AmLi neutron (\%) } \\
\text { (Oblinsk2 AmLi } \\
\text { Spectrum) }\end{array}$ & $\begin{array}{c}\text { \% } \\
\text { Difference } \\
\text { (Geiger } \\
\text { Zwan) }\end{array}$ & $\begin{array}{c}\text { \% } \\
\text { Difference } \\
\text { (Oblinsk2) }\end{array}$ \\
\hline $\mathbf{1}$ & 0.031 & 0.034 & 0.034 & $-8 \%$ & $-8 \%$ \\
\hline $\mathbf{2}$ & 0.072 & 0.089 & 0.090 & $-24 \%$ & $-26 \%$ \\
\hline $\mathbf{3}$ & 0.083 & 0.101 & 0.103 & $-22 \%$ & $-24 \%$ \\
\hline $\mathbf{4}$ & 0.074 & 0.083 & 0.083 & $-12 \%$ & $-13 \%$ \\
\hline $\mathbf{5}$ & 0.089 & 0.103 & 0.105 & $-16 \%$ & $-18 \%$ \\
\hline $\mathbf{6}$ & 0.124 & 0.140 & 0.142 & $-13 \%$ & $-14 \%$ \\
\hline $\mathbf{7}$ & 0.180 & 0.219 & 0.221 & $-22 \%$ & $-23 \%$ \\
\hline $\mathbf{8}$ & 0.191 & 0.229 & 0.231 & $-20 \%$ & $-21 \%$ \\
\hline
\end{tabular}

The variation in the doubles rates was suspected to be the result of slight discrepancies in the simulated fuel composition. Simulations with a fuel assembly comprised of $1.7 \%{ }^{235} \mathrm{U}$ by weight, which is between the weight percent of ${ }^{235} \mathrm{U}$ in the DU and LEU rods were performed and the results are shown in Table 4.5. As expected, the fuel composition has a more significant 
impact on the doubles rates than the singles rates, as the singles are dominated by the neutrons from the AmLi source (approximately a 30\% difference between doubles for the original LEU and modified LEU, and a 5\% difference for the singles). A slight discrepancy in the fuel composition would have a larger effect on the doubles rates and would vary depending on the LEU fuel pin location (as the neutrons incident upon the pins are dependent upon the fuel assembly configuration), which is consistent with what was seen in the comparison of the simulated and measured results (Table 4.4).

Table 4.5. Simulated singles and doubles in DU, LEU and modified LEU fuel compositions.

\begin{tabular}{|c|c|c|c|c||}
\hline $\begin{array}{c}\text { Fuel } \mathbf{( 2 3}_{\mathbf{U}}^{\mathbf{U}} \\
\mathbf{w t} \%)\end{array}$ & $\begin{array}{c}\text { Simulated } \\
\text { singles/emitted } \\
\text { AmLi neutron } \\
\mathbf{( \% )}(\mathbf{G - Z} \text { AmLi } \\
\text { Spectrum) }\end{array}$ & $\begin{array}{c}\text { Simulated } \\
\text { doubles/emitted } \\
\text { AmLi neutron (\%) } \\
\text { (G-Z AmLi } \\
\text { Spectrum) }\end{array}$ & $\begin{array}{c}\text { Simulated } \\
\text { singles/emitted } \\
\text { AmLi neutron (\%) } \\
\text { (Oblinsk2 AmLi } \\
\text { Spectrum) }\end{array}$ & $\begin{array}{c}\text { Simulated } \\
\text { doubles/emitted } \\
\text { AmLi neutron (\%) } \\
\text { (Oblins2 AmLi } \\
\text { Spectrum) }\end{array}$ \\
\hline $\begin{array}{c}\text { DU } \\
\mathbf{( 0 . 2 1 9 \% )}\end{array}$ & 7.18 & 0.034 & 7.00 & 0.034 \\
\hline $\begin{array}{c}\text { LEU } \\
(\mathbf{3 . 1 9 \% )}\end{array}$ & 8.64 & 0.229 & 8.48 & 0.231 \\
\hline $\begin{array}{c}\text { Modified } \\
(\mathbf{1 . 7 0 \% )}\end{array}$ & 8.23 & 0.161 & 8.05 & 0.162 \\
\hline
\end{tabular}

The GE-ABUNCL fuel chamber is rectangular, allowing for the fuel assembly to be shifted towards the front or back of the chamber. The effect of the fuel assembly position was examined through a series of measurements and simulations. Fuel array configuration number 8 (all LEU pins) was measured centered, shifted $3.75 \mathrm{~cm}$ towards the front of the detector (towards the AmLi source locations), and shifted $3.75 \mathrm{~cm}$ towards the back of the detector. The results are shown in Table 4.6 and Table 4.7. Note that the fuel assembly position has a greater effect on the doubles rates than the singles rates, primarily due to the singles being dominated by the neutrons from the AmLi source, as was previously noted.

Table 4.6. Measurements and simulations of the singles rates with the fuel assembly (Array Number 8) in the center of the chamber, shifted $3.75 \mathrm{~cm}$ towards the AmLi source $(+3.75 \mathrm{~cm})$ and shifted $3.75 \mathrm{~cm}$ away from the AmLi source $(-3.75 \mathrm{~cm})$.

\begin{tabular}{||c|c|c|c|c|c||}
\hline $\begin{array}{c}\text { Array } \\
\text { Position }\end{array}$ & $\begin{array}{c}\text { Measured } \\
\text { singles/emitted } \\
\text { AmLi neutron } \\
\mathbf{( \% )}\end{array}$ & $\begin{array}{c}\text { Simulated } \\
\text { singles/emitted } \\
\text { AmLi neutron (\%) } \\
\text { (G-Z AmLi } \\
\text { Spectrum) }\end{array}$ & $\begin{array}{c}\text { Simulated } \\
\text { singles/emitted } \\
\text { AmLi neutron } \\
(\%)(O b l i n s k 2 \\
\text { AmLi Spectrum) }\end{array}$ & $\begin{array}{c}\% \\
\text { difference } \\
\text { (Geiger } \\
\text { Zwan) }\end{array}$ & $\begin{array}{c}\% \\
\text { difference } \\
\text { (Oblinsk2) }\end{array}$ \\
\hline $\mathbf{C e n t e r}$ & 7.33 & 8.23 & 8.05 & $-18 \%$ & $-16 \%$ \\
\hline $\mathbf{+ 3 . 7 5} \mathbf{~ c m}$ & 7.12 & 7.95 & 7.78 & $-18 \%$ & $-16 \%$ \\
\hline $\mathbf{- 3 . 7 5} \mathbf{~ c m}$ & 7.40 & 8.31 & 8.15 & $-18 \%$ & $-16 \%$ \\
\hline
\end{tabular}


Table 4.7. Measurements and simulations of the doubles rates with the fuel assembly (Array Number 8) in the center of the chamber, shifted $3.75 \mathrm{~cm}$ towards the AmLi source $(+3.75 \mathrm{~cm})$ and shifted $3.75 \mathrm{~cm}$ away from the AmLi source $(-3.75 \mathrm{~cm})$.

\begin{tabular}{||c|c|c|c|c|c||}
\hline \hline $\begin{array}{c}\text { Array } \\
\text { Position }\end{array}$ & $\begin{array}{c}\text { Measured } \\
\text { doubles/emitted } \\
\text { AmLi neutron } \\
(\%)\end{array}$ & $\begin{array}{c}\text { Simulated } \\
\text { doubles/emitted } \\
\text { AmLi neutron (\%) } \\
\text { (G-Z AmLi } \\
\text { Spectrum) }\end{array}$ & $\begin{array}{c}\text { Simulated } \\
\text { doubles/emitted } \\
\text { AmLi neutron } \\
(\%) \text { (Oblinsk2 } \\
\text { AmLi Spectrum) }\end{array}$ & $\begin{array}{c}\% \\
\text { difference } \\
\text { (Geiger } \\
\text { Zwan) }\end{array}$ & $\begin{array}{c}\text { \% } \\
\text { difference } \\
(\text { Oblinsk2) }\end{array}$ \\
\hline Center & 0.19 & 0.23 & 0.23 & $-20 \%$ & $-21 \%$ \\
\hline $\mathbf{+ 3 . 7 5} \mathbf{~ c m}$ & 0.20 & 0.24 & 0.25 & $-22 \%$ & $-23 \%$ \\
\hline $\mathbf{- 3 . 7 5} \mathbf{~ c m}$ & 0.18 & 0.22 & 0.22 & $-22 \%$ & $-23 \%$ \\
\hline
\end{tabular}

Simulations with the UNCL-II and the various fuel array configurations were also performed. Measurements were not performed during this research effort with the UNCL-II, thus the simulated values only are presented in Table 4.8 .

Table 4.8. Simulated doubles with the UNCL-II and the eight different fuel array assemblies compared to the simulated doubles with the GE-ABUNCL.

\begin{tabular}{|c|c|c|}
\hline $\begin{array}{c}\text { Array } \\
\text { Number }\end{array}$ & $\begin{array}{c}\text { Simulated } \\
\text { doubles/emitted } \\
\text { AmLi neutron (\%) } \\
\text { UNCL-II (Geiger } \\
\text { Zwan AmLi } \\
\text { Spectrum) }\end{array}$ & $\begin{array}{c}\text { Simulated } \\
\text { doubles/emitted } \\
\text { AmLi neutron (\%) } \\
\text { UNCL-II (Oblinsk2 } \\
\text { AmLi Spectrum) }\end{array}$ \\
\hline $\mathbf{1}$ & 0.050 & 0.051 \\
\hline $\mathbf{2}$ & 0.133 & 0.134 \\
\hline $\mathbf{3}$ & 0.152 & 0.156 \\
\hline $\mathbf{4}$ & 0.133 & 0.135 \\
\hline $\mathbf{5}$ & 0.148 & 0.149 \\
\hline $\mathbf{6}$ & 0.209 & 0.209 \\
\hline $\mathbf{7}$ & 0.303 & 0.333 \\
\hline $\mathbf{8}$ & 0.347 & 0.347 \\
\hline
\end{tabular}

The UNCL-II singles were also simulated, and are shown in Appendix B. The singles rate is primarily a function of the AmLi source. 


\section{Conclusions}

This report discussed the modeling of fuel measured with a full-scale ABUNCL coincidence counter developed by GE Reuter-Stokes for applications in safeguards under the project Coincidence Counting With Boron-Based Alternative Neutron Detection Technology.

The GE-ABUNCL MCNP simulations were performed with MCNP6 v1.0 using the FT8 CAP EDEP option. Before the availability of this (new) option, the FT8 CAP treatment (in MCNPX) for calculating multiplicity moments was applicable only to counters where the capture and signal generation took place in the same cell. Simulations were performed to compare the singles generated with the this new option to the total-capture results previously simulated with MCNPX using the FT8 PHL tally, and as expected, they were statistically identical. However, the double rates evaluated with the new FT8 CAP EDEP treatment are new and essential for simulating ${ }^{10} \mathrm{~B}$ lined proportional counters. This report presents one of the first applications of this new MCNP option. Simulations were performed with models of the previously measured fuel assembly configurations, and the results of the simulations were found to be within approximately $25 \%$ of the measured data. The difference between the simulated and measured results would likely be improved with a more precise model of the fuel assembly and measurement of a wellcharacterized fuel assembly.

The same set of simulations performed with the GE-ABUNCL was also performed with a model of the UNCL-II BWA Active counter - the ${ }^{3} \mathrm{He}$-based system that the GE-ABUNCL is designed to replace. The singles efficiency with the UNCL-II was lower than with the GE-ABUNCL, although the doubles efficiency was higher. The difference was demonstrated to be due to the higher rate of detection of the AmLi neutrons in the GE-ABUNCL than the UNCL-II because of the increased amount of polyethylene in the GE-ABUNCL. Confirmation of these simulated UNCL-II results with actual measurements for the same source and fuel would be very useful. The results presented here indicate that the Geiger-Van de Zwan and the Oblinsk2 AmLi source spectra do not produce an appreciable difference in the doubles rates. The results also demonstrate that the EDEP CAP tally can be applied to systems constructed with ${ }^{10} \mathrm{~B}$-lined proportional counters.

Future work could include further measurements of fuel assemblies and simpler configurations to identify why the models consistently overestimate the system response. 


\section{Acknowledgements}

The United States Department of Energy Office of Nuclear Safeguards and Security (NA-241) supported this work. Pacific Northwest National Laboratory is operated for the United States Department of Energy under contract DE-AC05-76RLO 1830. Azaree Lintereur was a post Masters Research Assistant supported at Pacific Northwest National Laboratory by the Next Generation Safeguards Initiative, Office of Nuclear Safeguards and Security, National Nuclear Security Administration. 


\section{References}

Croft S, A Favalli, MT Swinhoe, CD Rael. 2011. "State Of The Art Monte Carlo Modeling Of Active Collar Measurements And Comparison With Experiment." Los Alamos National Laboratory. INMM Conference Record 2011.

Canberra. 2011. "Model JCC-71, 72 and 73 Neutron Coincidence Collars." Accessed at www.canberra.com.

Goorley JT, et al. 2012. “Initial MCNP 6 Release Overview.” LA-UR-11-07082, Los Alamos National Laboratory.

Hendricks JS, et al. 2005. "MCNPX Extensions, Version 2.5.0.” LA-UR-05-2675, Los Alamos National Laboratory.

Henzlova D, LG Evans, HO Menlove, MT Swinhoe, JB Marlow. 2010. "Draft Test Program to Compare Alternative Neutron Detectors for Potential ${ }^{3} \mathrm{He}$ Replacement for Nuclear Safeguards Applications." Technical Report LA-UR-11-00098, Los Alamos National Laboratory.

Henzlova D, LG Evans, HO Menlove, MT Swinhoe, V Henzl, C Rael, JB Marlow. 2012. "Results of Evaluation and Comparison of Alternative Neutron Detectors for Potential ${ }^{3} \mathrm{He}$ Replacement for Nuclear Safeguards Applications.” Technical Report LA-UR-12-00837, Los Alamos National Laboratory.

Kouzes RT, JH Ely, LE Erikson, WJ Kernan, AT Lintereur, ER Siciliano, DL Stephens, DC Stromswold, RM Van Ginhoven, and ML Woodring. 2010. "Neutron detection alternatives to ${ }^{3}$ He for national security applications." Nuclear Instruments and Methods in Physics Research A, 623(3):1035-1045.

Kouzes RT, JH Ely, AT Lintereur, and ER Siciliano. 2012. "Boron-10 ABUNCL Prototype Initial Testing.” Technical Report PNNL-22147. Pacific Northwest National Laboratory, Richland, WA.

Kouzes RT, JH Ely, AT Lintereur, and ER Siciliano. 2013. "Boron-10 ABUNCL Prototype Models and Initial Active Testing." Technical Report PNNL-22424. Pacific Northwest National Laboratory, Richland, WA.

Kouzes RT, JH Ely, AT Lintereur, and ER Siciliano. 2013b. "Boron-10 ABUNCL Active Testing." Technical Report PNNL-22567. Pacific Northwest National Laboratory, Richland, WA.

Krick M and W Geist. 2009. "INCC Software Users Manual.” Technical Report LA-UR-106227, Los Alamos National Laboratory.

Pelowitz DB (ed.). 2011. “MCNPX User's Manual”, Version 2.7.0. Technical Report LA-CP-1100438 Los Alamos National Laboratory.

McKinny, K, T Anderson, N Johnson, E Weissman. 2012. Presentation at the IEEE Nuclear Science Symposium, Anaheim. CA, October 29, 2012. 
Menlove HO. 1981. "Description and Performance Characteristics for the Neutron Coincidence Collar for the Verification of Reactor Fuel Assemblies.” Technical Report LA-8939-MS, Los Alamos National Laboratory.

Menlove HO, JE Stewart, SZ Qiao, TR Wenz, PD Verrecchia. 1990. "Neutron Collar Calibration and Evaluation for Assay of L WR Fuel Assemblies Containing Burnable Neutron Absorbers." Los Alamos National Laboratory Report LA-11965-MS.

Menlove HO, D Henzlova, LG Evans, MT Swinhoe, and JB Marlow. 2011. “3 He Replacement for Nuclear Safeguards Applications - an Integrated Test Program to Compare Alternative Neutron Detectors." ESARDA Bulletin 46.

Pelowitz DB (ed.). 2011. “MCNPX User's Manual”, Version 2.7.0. Los Alamos National Laboratory Report LA-CP-11-00438.

Siciliano ER, JL Rogers, JE Schweppe, AT Lintereur, and RT Kouzes. 2012. "Uranium Neutron Coincidence Collar Model Utilizing ${ }^{3}$ He.” Technical Report PNNL-21581. Pacific Northwest National Laboratory, Richland, WA.

Swinhoe MT, and JS Hendricks. 2011. "Calculation of the Performance of 3He Alternative Detectors with MCNPX." $2^{\text {nd }}$ International ANIMMA Conference, Ghent, Belgium.

Swinhoe MT, JS Hendricks, and DR Mayo. 2005. "MCNPX for Neutron Multiplicity Detector Simulation.” Technical Report LA-UR-053155, Los Alamos National Laboratory. 


\section{Appendix A}

The polyethylene moderator in the counter affects the system efficiency. This effect was examined by decreasing the size of the active block for the GE-ABUNCL, and increasing the size of the block for the UNCL-II, Figure 8.1. Additional alterations were made to the total volume of polyethylene present in the UNCL-II by changing the counter height and the counter foot-print, with the active source block the same height as that of the GE-ABUNCL. The first total system change performed with the UNCL-II was an increase in the height of the polyethylene around the tubes to be the same height as the polyethylene walls of the GEABUNCL. The second change to the UNCL-II was to increase the width of the polyethylene blocks by $2 \mathrm{~cm}$ behind the tubes, while keeping the extended height. The second change resulted in approximately the same total volume of polyethylene in the UNCL-II as is present in the GEABUNCL. The final configuration change was to increase the height of the ${ }^{3} \mathrm{He}$ tubes to scale with the polyethylene block height. The series of three UNCL-II changes is shown in Figure 8.2. Note that the number of tubes in the UNCL-II was not increased during the configuration changes. The number of collisions per neutron in both the active source block (ASB) and the tube block (TB) increased with the amount of polyethylene (for an AmLi source in the ASB), as can be seen in Table 8.1. The higher number of collisions increases the probability of a capture occurring, which produces a higher efficiency in the GE-ABUNCL than the UNCL-II when the source is in the ASB.

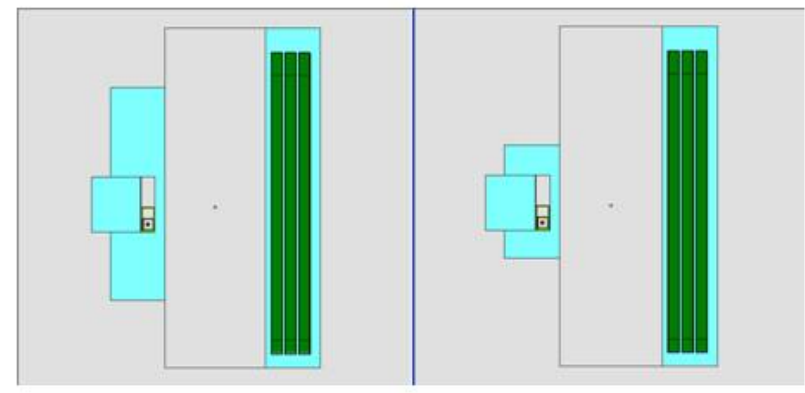

a

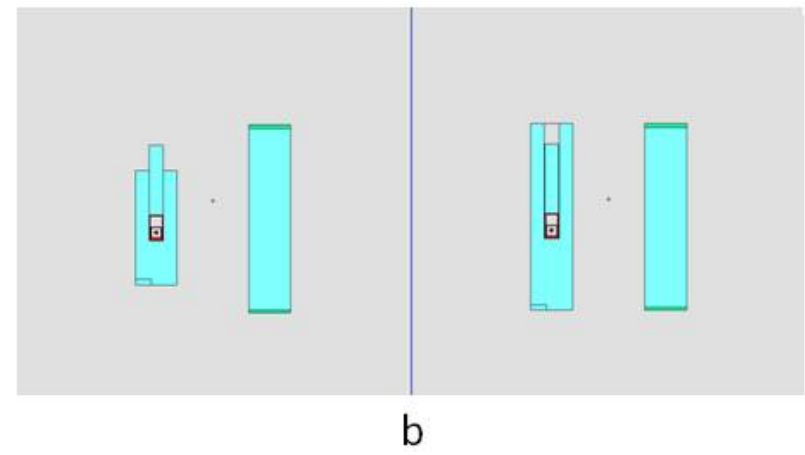

Figure 8.1. Active source block polyethylene volume alterations for the (a) GE-ABUNCL and (b) the UNCL-II. The images on the left show the original active block and the images on the right show the modified active blocks. 


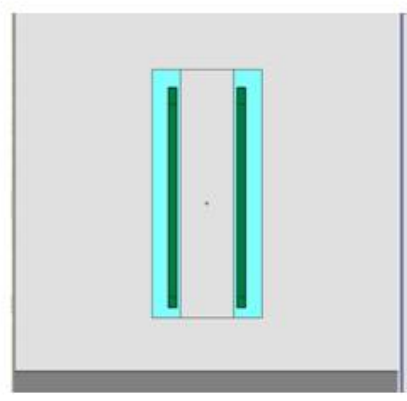

a

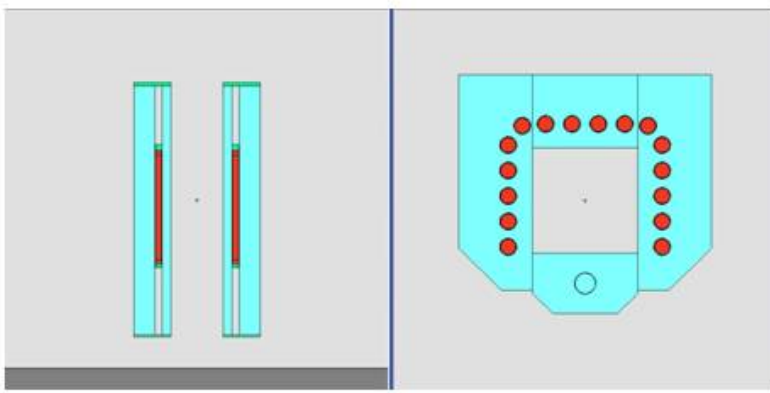

C
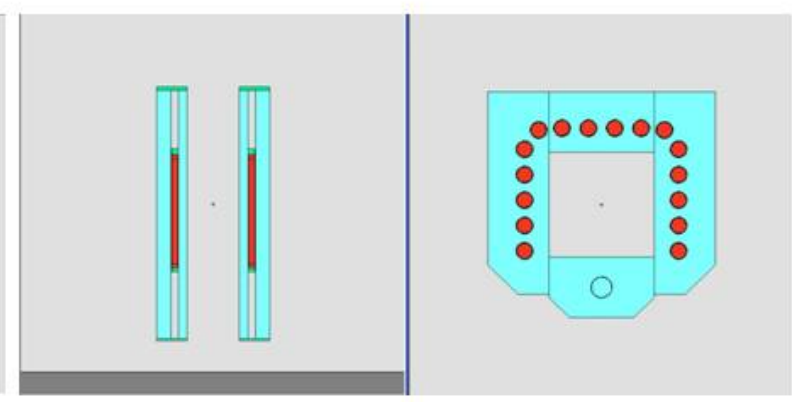

b

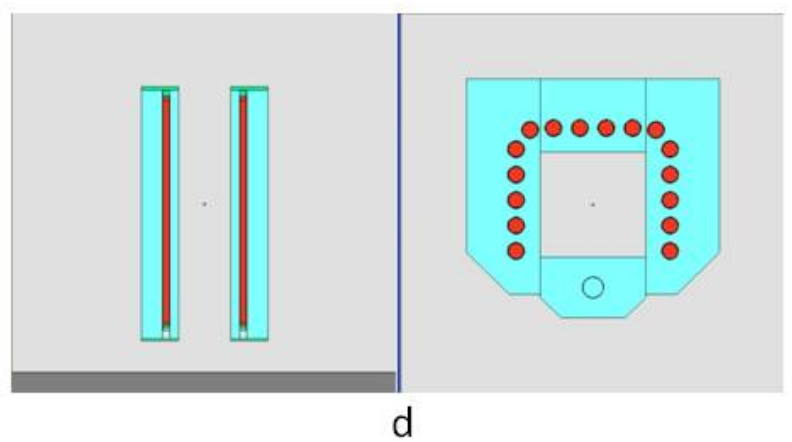

Figure 8.2. Polyethylene variations for the UNCL-II. The GE-ABUNCL footprint (a) is shown for comparison. An increase in the UNCL-II height to be the same as the GE-ABUNCL is shown in (b), the UNCL-II polyethylene volume change to be approximately equivalent to the GE-ABUNCL polyethylene volume is shown in (c), and the same polyethylene configuration, but with the tube size also increased to be the same as the GE-ABUNCL tube height, is shown in (d). 
Table 8.1. The effect of the active source block dimensions on the neutron collisions and captures for both counters, and the effect of changes in the total amount of polyethylene on the neutron collisions and captures in the UCNL-II.

\begin{tabular}{|c|c|c|c|c||}
\hline $\begin{array}{c}\text { Configuration } \\
\text { (one AmLi source in } \\
\text { the active } \\
\text { configuration source } \\
\text { holder, no fuel) }\end{array}$ & $\begin{array}{c}\text { Neutrons captured in } \\
\text { and escaped from the } \\
\text { total system (with no } \\
\text { other loss } \\
\text { mechanisms) }\end{array}$ & $\begin{array}{c}\text { Average number } \\
\text { of collisions in } \\
\text { the active block } \\
\text { per emitted } \\
\text { neutron }\end{array}$ & $\begin{array}{c}\text { Average number } \\
\text { of collisions in } \\
\text { the tube blocks } \\
\text { per emitted } \\
\text { neutron }\end{array}$ & $\begin{array}{c}\text { Simulated cps } \\
\text { per emitted } \\
\text { source } \\
\text { neutron }\end{array}$ \\
\hline GE-ABUNCL & $85 \% / 15 \%$ & 83 & 25 & $8.3 \%$ \\
\hline $\begin{array}{c}\text { GE-ABUNCL with } \\
\text { UNCL-II AB height }\end{array}$ & $80 \% / 20 \%$ & 74 & 24 & $8.0 \%$ \\
\hline UNCL-II & $59 \% / 41 \%$ & 79 & 16 & $5.6 \%$ \\
\hline $\begin{array}{c}\text { UNCL-II with GE- } \\
\text { ABUNCL AB height }\end{array}$ & $61 \% / 39 \%$ & 81 & 22 & $5.8 \%$ \\
\hline $\begin{array}{c}\text { UNCL-II with GE- } \\
\text { ABUNCL AB and } \\
\text { TB height }\end{array}$ & $64 \% / 36 \%$ & 81 & 23 & $6.0 \%$ \\
\hline $\begin{array}{c}\text { UNCL-II with GE- } \\
\text { ABUNCL AB and } \\
\text { TB dimensions }\end{array}$ & $65 \% / 35 \%$ & 81 & 21 & $6.1 \%$ \\
\hline $\begin{array}{c}\text { UNCL-II with GE- } \\
\text { ABUNCL AB and } \\
\text { TB dimensions } \\
\text { extended tubes }\end{array}$ & $65 \% / 35 \%$ & 81 & & $7.7 \%$ \\
\hline
\end{tabular}

Note that although there are approximately $30 \%$ more neutrons captured in the GE-ABUNCL than the UNCL-II (for the same polyethylene volume) the efficiency of the GE-ABUNCL is only approximately $8 \%$ higher. This is due to the fact that not all of the neutrons captured in the ${ }^{10} \mathrm{~B}$ lining will generate a signal, whereas for the ${ }^{3} \mathrm{He}$ filled tubes, the neutron capture and signal generating media are the same. Also note that the reported number of neutrons captured is the number captured in the counter, not solely in the tubes. 


\section{Appendix B}

The simulated singles rate for the UNCL-II and a comparison with the GE-ABUNCL simulated singles rate is presented below. A volumetric fuel study illustrating the effect of the amount of fuel in the chamber on the singles rate in an active counter is also presented.

It can be seen in Table 9.1 that the simulated GE-ABUNCL singles efficiency is higher than the simulated UNCL-II singles efficiency with an AmLi source in the active panel and a fuel assembly in the sample chamber. However, the simulated doubles efficiency of the GEABUNCL is lower than the simulated doubles efficiency of the UNCL-II, as was listed in Table 4.8 .

A volumetric study of the fuel assembly in the sample chamber, shown in Figure 9.1, was performed for two of the fuel array configurations (1 and 8). The results with the different fuel heights for both the GE-ABUNCL and the UNCL-II, listed in Table 9.2 and Table 9.3, demonstrate that the higher GE-ABUNCL singles rate is primarily due to the AmLi neutron detections, which was shown to be influenced by the polyethylene volume of the counter in Appendix A (Table 8.1).

Table 9.1. Simulated singles with the UNCL-II for the eight different fuel array assemblies, compared to the simulated singles with the GE-ABUNCL (Table 4.3). The percent difference was calculated using the simulated UNCL-II rates as the actual rates.

\begin{tabular}{|c|c|c|c|c||}
\hline $\begin{array}{c}\text { Array } \\
\text { Number }\end{array}$ & $\begin{array}{c}\text { Simulated } \\
\text { cps/emitted AmLi } \\
\text { neutron (\%) } \\
\text { UNCL-II (Geiger } \\
\text { Zwan AmLi } \\
\text { Spectrum) }\end{array}$ & $\begin{array}{c}\text { Simulated } \\
\text { cps/emitted AmLi } \\
\text { neutron (\%) } \\
\text { UNCL-II } \\
\text { (Oblinsk2 AmLi } \\
\text { Spectrum) }\end{array}$ & $\begin{array}{c}\text { \% difference } \\
\text { (with GE- } \\
\text { ABUNCL) } \\
\text { (Geiger } \\
\text { Zwan) }\end{array}$ & $\begin{array}{c}\text { \% difference } \\
\text { (with GE- } \\
\text { ABUNCL) } \\
\text { (Oblinsk2) }\end{array}$ \\
\hline $\mathbf{1}$ & 4.8 & 4.6 & $-51 \%$ & $-53 \%$ \\
\hline $\mathbf{2}$ & 5.5 & 5.3 & $-40 \%$ & $-41 \%$ \\
\hline $\mathbf{3}$ & 5.6 & 5.5 & $-37 \%$ & $-39 \%$ \\
\hline $\mathbf{4}$ & 5.3 & 5.2 & $-41 \%$ & $-42 \%$ \\
\hline $\mathbf{5}$ & 5.7 & 5.6 & $-36 \%$ & $-38 \%$ \\
\hline $\mathbf{6}$ & 6.1 & 5.6 & $-32 \%$ & $-41 \%$ \\
\hline $\mathbf{7}$ & 6.9 & 6.7 & $-25 \%$ & $-25 \%$ \\
\hline $\mathbf{8}$ & 7.0 & 6.8 & $-24 \%$ & $-24 \%$ \\
\hline
\end{tabular}



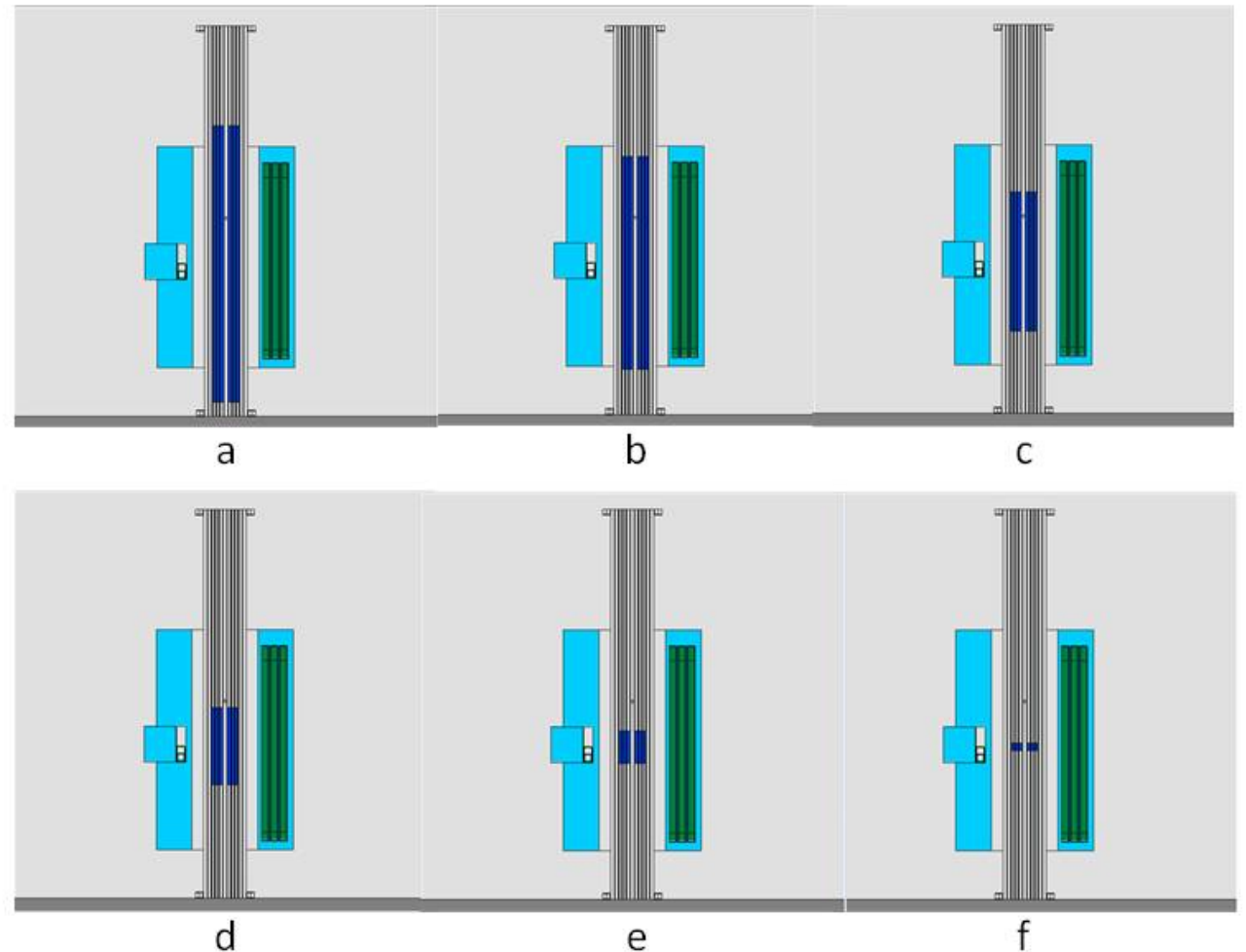

Figure 9.1. Variations in fuel height simulated in both the GE-ABUNCL (shown) and the UNCL-II (not shown). The seventh simulated height (h) is not shown.

Table 9.2. Fuel height study with Array number 1 (all DU) and Array number 8 (all LEU) with the GE-ABUNCL. The original fuel assembly height was $128.0 \mathrm{~cm}$.

\begin{tabular}{|c|c|c|c|c|}
\hline Fuel Height & $\begin{array}{c}\text { GE-ABUNCL } \\
\text { Array } 1 \text { Singles }\end{array}$ & $\begin{array}{l}\text { GE-ABUNCL } \\
\text { Array } 8 \text { Singles }\end{array}$ & $\begin{array}{c}\text { GE-ABUNCL } \\
\text { Array } 1 \text { Doubles }\end{array}$ & $\begin{array}{c}\text { GE-ABUNCL } \\
\text { Array } 8 \text { Doubles }\end{array}$ \\
\hline a $(97.658 \mathrm{~cm})$ & 7.18 & 8.64 & 0.0335 & 0.23 \\
\hline b $(75.460 \mathrm{~cm})$ & 7.18 & 8.62 & 0.0331 & 0.23 \\
\hline c $(49.460 \mathrm{~cm})$ & 7.12 & 8.47 & 0.0302 & 0.21 \\
\hline d $(27.460 \mathrm{~cm})$ & 7.11 & 8.16 & 0.0221 & 0.16 \\
\hline e $(11.460 \mathrm{~cm})$ & 7.41 & 7.99 & 0.0117 & 0.08 \\
\hline$f(2.540 \mathrm{~cm})$ & 7.72 & 7.91 & 0.0026 & 0.03 \\
\hline $\mathrm{g}(0.100 \mathrm{~cm})$ & 7.82 & 7.84 & 0.0003 & 0.004 \\
\hline
\end{tabular}


Table 9.3. Fuel height study with Array number 1 (all DU) and Array number 8 (all LEU) with the UNCL-II. The original fuel assembly height was $128.0 \mathrm{~cm}$.

\begin{tabular}{|c|c|c|c|c|}
\hline Fuel Height & $\begin{array}{c}\text { UNCL-II } \\
\text { Array } 1 \text { Singles }\end{array}$ & $\begin{array}{c}\text { UNCL-II } \\
\text { Array } 8 \text { Singles }\end{array}$ & $\begin{array}{c}\text { UNCL-II } \\
\text { Array } 1 \text { Doubles }\end{array}$ & $\begin{array}{c}\text { UNCL-II } \\
\text { Array } 8 \text { Doubles }\end{array}$ \\
\hline a $(97.658 \mathrm{~cm})$ & 4.75 & 6.98 & 0.0501 & 0.35 \\
\hline b $(75.460 \mathrm{~cm})$ & 4.75 & 6.98 & 0.0499 & 0.35 \\
\hline c $(49.460 \mathrm{~cm})$ & 4.73 & 6.93 & 0.0496 & 0.34 \\
\hline d $(27.460 \mathrm{~cm})$ & 4.55 & 6.38 & 0.0406 & 0.28 \\
\hline e $(11.460 \mathrm{~cm})$ & 4.86 & 5.89 & 0.0197 & 0.15 \\
\hline f $(2.540 \mathrm{~cm})$ & 5.1 & 5.46 & 0.0050 & 0.05 \\
\hline $\mathrm{g}(0.100 \mathrm{~cm})$ & 5.16 & 5.21 & 0.0005 & 0.006 \\
\hline
\end{tabular}

The doubles efficiency scales with the amount of the fuel assembly located within the counter chamber, as expected, because the AmLi source produces only singles. While the singles efficiency is affected by the presence of the fuel, the correlation is not as strong as with the doubles. Also note that the singles decrease when the fuel assembly is all DU because AmLi neutrons that would otherwise be detected are lost due to interactions with the fuel assembly that do not produce additional neutrons. The results in Table 9.1 and Table 9.2 illustrate why the simulated GE-ABUNCL singles efficiency is higher than the UNCL-II, but the GE-ABUNCL doubles efficiency is lower than that of the UNCL-II. 


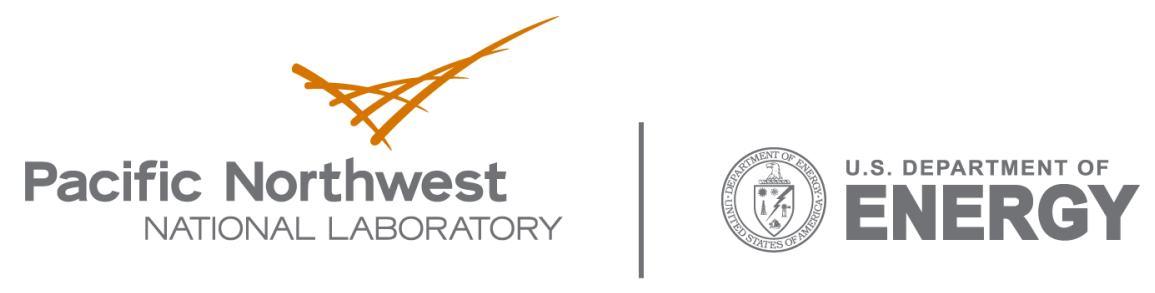

902 Battelle Boulevard

P.O. Box 999

Richland, WA 99352

1-888-375-PNNL (7665)

www.pnl.gov 